\title{
PENDUGAAN DAERAH RAWAN LONGSOR BERBASIS SISTEM INFORMASI GEOGRAFIS DI CAGAR ALAM PEGUNUNGAN ARFAK
}

\section{(Predicting Erosion Vulnerable Area Based on Geographical Information System in Pegunungan Afrak Nature Reserve)}

\author{
Saremay MR Sawaki ${ }^{1}$ Hans FZ Peday ${ }^{1 \bowtie}$ dan Devi Manuhua ${ }^{1}$ \\ Jurusan Kehutanan, Fakultas Kehutanan Universitas Papua Manokwari, Papua Barat, \\ 98314. Tlp/Fax: +62986211065 . \\ ${ }^{\square}$ Penulis Korespondensi: Email: hanspeday@yahoo.com \\ Diterima: 30 Oct 2018| Disetujui: 20 Nov 2018
}

\begin{abstract}
Abstrak
Penelitian ini bertujuan untuk mengetahui tingkat kerentanan longsor dan peta penyebarannya di kawasan Cagar Alam Pegunungan Arfak dimana dari hasil kajian ini diharapkan dapat memberikan informasi secara umum tentang tingkat kerentanan longsor pada daerah rawan longsor di kawasan CAPA. Metode yang digunakan dalam penelitian ini adalah deskriptif dengan melihat pengaruh dari masing-masing variabel longsor guna menentukan tingkat kerentanan longsor dengan variable utama yang diamati antara lain: faktor kelerengan, curah hujan dan jenis tanah. Hasil penelitian memperlihatkan bahwa terdapat beberapa kelas lereng pada kasawan CAPA dimana sebagian besar wilayah berada pada tingkat kelerengan $>45^{\circ}$. Sementara jenis tanah yang dominan yakni dari jenis kompleks podsolik, alluvial dan latosol. Namun secara umum, intensitas curah hujan terlihat cukup kecil. Dari hasil analisis, luas kawasan yang rawan terjadi longsor sebesar $53.753,78(64,56 \%)$, luas Kawasan dengan tingkat kerawanan sedang sebesar 25.815,58 $(31,00 \%)$ dan luas kawasan yang tidak rawan sebesar 3.681,65 (4,42\%).
\end{abstract}

Kata kunci: Longsor, tingkat kerawanan, kawasan cagar alam, data spasial.

\begin{abstract}
This study focuses on identifying sliding vulnerable rate and its distribution maps in Pegunungan Arfak natural reserve of which from the study, information regarding vulnerable rate of erosion in the surrounding areas can be unveiled. Descriptive method has been implemented by way of observing the effect of each erosion variable on determining sliding vulnerable rate through main parameters such as sloping factor, rainfall rate, and soil type. The result pointed out that there were sloping classes in Pegunung Arfak nature reserve in which most of the areas was $>45^{\circ}$. While, the dominant soil characteristic was complex podzolic, alluvial, and latosol. On the flip side, rainfall rate has been low. Based on the analysis indicated that the potential area to be vulnerable for erosion was 53,753.78 (64.56\%), slightly potential erosion area was about 25,815.58 $(31.00 \%)$, while the less vulnerable area was approximately 3,681.65 (4.42\%).
\end{abstract}

Keywords: Erosion, vulnerable rate, nature reserve area, spatial data. 


\section{PENDAHULUAN}

Cagar Alam Pegunungan Arfak (CAPA) secara administratif wilayah berada pada tiga Kabupaten yaitu Kabupaten Manokwari, Kabupaten Manokwari Selatan dan Kabupaten Pegunungan Arfak. CAPA memiliki potensi sumberdaya alam yang sangat besar dan potensi sumberdaya alam ini dapat dijaga dan dicegah dari bencana yang dapat ditimbulkan oleh manusia berupa eksploitasi namun tidak dapat dicegah dari bencana alam ( $\mathrm{Yu}$ et al. 2018).

Bencana alam sebagai suatu fenomena alam yang dapat terjadi setiap saat tanpa mengenal tempat dan waktu, sehingga dapat menimbulkan kerugian baik kategori material dan bukan material bagi kehidupan bermasyarakat. Bencana longsor adalah salah satu bencana alam yang sering mengakibatkan kerugian harta benda maupun korban jiwa dan menimbulkan kerusakan sarana dan prasarana lainnya yang bisa berdampak pada kondisi ekonomi dan sosial (Purnomo dan Sugiantoro 2010). Bencana alam tanah longsor dapat terjadi karena pola pemanfaatan lahan yang tidak mengikuti kaidah (aturan) kelestarian lingkungan, seperti gundulnya hutan akibat deforestasi dan konversi hutan menjadi lahan pertanian dan pemukiman pada lahan yang memiliki kemiringan lereng terjal. Kejadian longsor disebabkan oleh ketidakstabilan lahan yang pada umumnya diakibatkan oleh ulah manusia (Anwar 2003).

Ketidakstabilan lahan terjadi karena dua faktor, pertama hilangnya tumbuhan atau pohon-pohon di dataran tinggi yang memiliki fungsi mengikat butir-butir tanah sekaligus menjaga pori-pori tanah dibawahnya sehingga infiltrasi (aliran air ke dalam tanah) air hujan berjalan lancar. Kedua, akibat eksploitasi lahan miring yang tidak tepat misalnya pembangunan pemukiman dengan memotong tebing atau pengambilan tanah atau pasir di daerah bawah yang berlebihan. Kedua faktor tersebut jika dipicu oleh adanya hujan lebat yang datang secara tiba-tiba, maka akan berdampak pada tidak mampunya tanah menahan hantaman air hujan dan tergelincir ke bawah.

Bencana longsor yang terjadi pada 17 April 2016 di Distrik Hink dan Distrik Minyambouw yang merupakan bagian dari kawasan Cagar Alam Pegunungan Arfak ini memutuskan jalur transportasi dari Kabupaten Manokwari menuju pusat pemerintahan di Kabupaten Pegunungan Arfak (Cahaya Papua 2016). Dengan kondisi demikian maka perlu dilakukan analisis tingkat kerentanan longsor pada CAPA sehingga dapat diketahui daerahdaerah yang notabene merupakan kawasan dan areal yang rawan terjadi longsor.

Sistem informasi geografis (SIG) bermanfaat untuk pengawasan daerah bencana alam misalnya memantau luas wilayah bencana alam, pencegahan terjadinya bencana alam pada masa datang, menyusun rencana-rencana pembangunan kembali daerah bencana, penentuan tingkat bahaya erosi, prediksi ketinggian banjir dan prediksi tingkat kekeringan (BNPB 2009; Qashlim 2013). Tujuan dilakukannya penelitian ini adalah untuk mengetahui tingkat kerentanan longsor dan peta penyebarannya di wilayah Cagar Alam Pegunungan Arfak dan manfaat yang diharapkan yaitu dapat memberikan informasi secara umum tentang tingkat kerentanan longsor pada daerah rawan longsor di kawasan CAPA 
kepada pemerintah dan masyarakat umum serta pihak-pihak terkait yang membutuhkan.

\section{METODE PENELITIAN}

\section{Lokasi dan Waktu}

Penelitian ini dilangsungkan dari bulan Mei hingga Juni thaun 2017 dengan 2 tahapan yaitu analisis pengolahan data awal dan data lanjutan pada Laboratorium GIS Fakultas Kehutanan UNIPA Manokwari dan kegiatan survei lapangan pada kawasan Cagar Alam Pegunungan Arfak (peninjauan lapangan/ground check dilakukan pada lokasi yang paling dekat dengan akses jalan).

\section{Metode Penelitian}

Metode yang akan digunakan dalam penelitian ini adalah secara deskriptif dengan melihat pengaruh dari masingmasing variabel longsor guna menentukan tingkat kerentanan longsor pada Kawasan CAPA. Variabel yang diamati dalam penelitian ini adalah faktor kelerengan, curah hujan dan jenis tanah
(Surat Keputusan Menteri Pertanian Nomor $837 / \mathrm{Kpts} / \mathrm{Um} / 11 / 1980$ tanggal 24 November 1980 tentang Kriteria dan Tata Cara Penetapan Hutan Lindung).

\section{Tahapan Penelitian}

Tahapan penelitian dibuat agar suatu penelitian dapat dilakukan dengan tersusun dan terencana. Tahapan penelitian ini dilakukan dengan 3 tahapan utama yaitu: tahap persiapan, tahap penelitian, dan hasil. Tahap persiapan meliputi: identifikasi dan perumusan masalah, studi literatur dan pengumpulan data penunjang. Tahapan penelitian meliputi: pengolahan data dan analisis data. Sementara tahapan hasil meliputi: kesimpulan, saran, dan rekomendasi. Analisis yang digunakan dalam penelitian ini adalah analisis secara kuantitatif (berdasar pada jumlah) dengan teknik penggabungan/tumpang tindih (overlay) terhadap variabel kerawanan dengan bantuan sistem informasi geografis (SIG). Tahapan penelitian dapat dilihat pada Gambar 1.

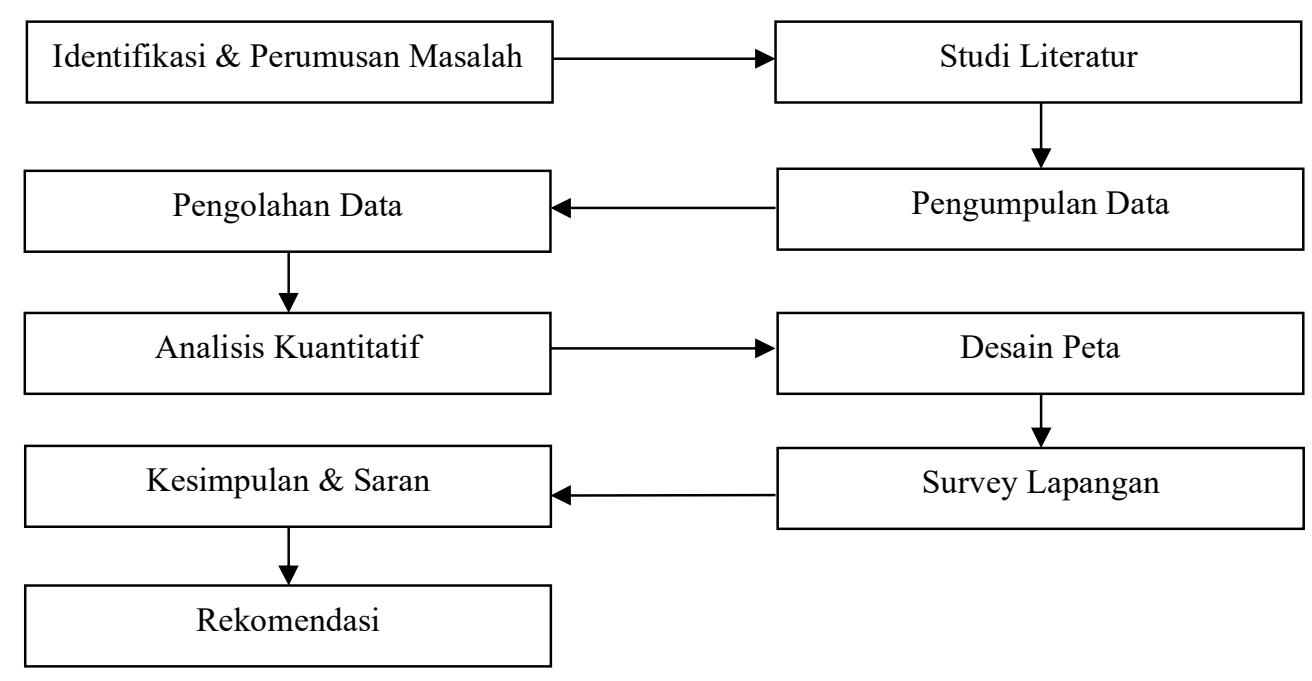

Gambar 1. Alur penelitian 


\section{Teknik Pengolahan Data}

\section{Pengolahan Data Spasial}

Data yang telah siap diolah/dianalisis dengan menggunakan ArcGIS 10.2.2 pada umumnya harus dalam bentuk tipe data atau format shape file (shp.) karena format tersebut merupakan format standar dalam pengelolaan data spasial yang dapat dibaca oleh program-program standar sistem informasi geografis (SIG). Alur analisis data dapat dilihat pada Gambar 2.

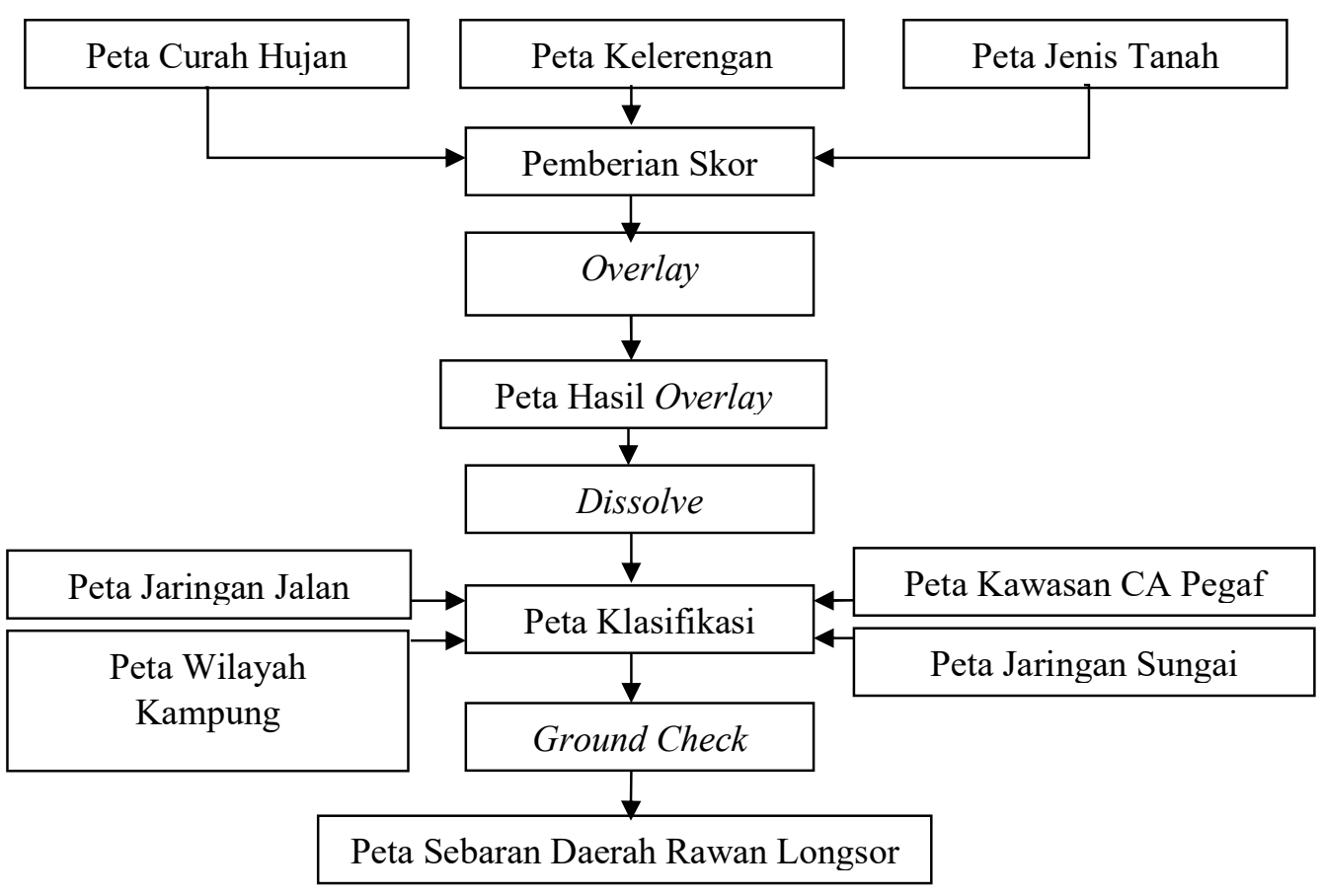

Gambar 2. Alur Pengolahan Data

Skoring Parameter Kerentanan Longsor

Harkat atau skor adalah pemberian nilai terhadap suatu polygon peta untuk memberikan tindak kedekatan, keterkaitan, atau beratnya dampak tertentu pada suatu fenomena secara spasial (Budiyanto 2016). Skor timbangan pada kelas lereng 20, intensitas curah hujan 10, dan jenis tanah
15 sesuai dengan Surat Keputusan Menteri Pertanian Nomor $837 / \mathrm{Kpts} / \mathrm{Um} / 11 / 1980$ tanggal 24 November 1980 tentang Kriteria dan Tata Cara Penetapan Hutan Lindung. Pemberian skor dan pengkelasan lereng dibagi dalam lima kelas dan dapat dilihat pada Tabel 1. 
Tabel 1. Kelas kelerengan dan nilai skor

\begin{tabular}{ccccc}
\hline Kelas & Kelerengan $(\%)$ & Kriteria & Keterangan & Skor \\
\hline 1. & $>45 \%$ & Sangat Curam & Sangat Peka & 100 \\
2. & $25-45 \%$ & Curam & Peka & 80 \\
3. & $15-25 \%$ & Agak Curam & Kepekaan Sedang & 60 \\
4. & $8-15 \%$ & Landai & Agak Peka & 40 \\
5. & $0-8 \%$ & Datar & Tidak Peka & 20 \\
\hline
\end{tabular}

Sumber: Surat Keputusan Menteri Pertanian Nomor 837/Kpts/Um/1 1/1980

Tabel 2. Kelas kepekaan tanah terhadap erosi dan nilai skor

\begin{tabular}{clcc}
\hline Kelas & \multicolumn{1}{c}{ Kriteria } & Keterangan & Skor \\
\hline 1. & $\begin{array}{l}\text { Aluvial, Gleisol, Planosol, Hidromorf } \\
\text { Kelabu, Laterik Air Tanah }\end{array}$ & Tidak Peka & 15 \\
2. & $\begin{array}{l}\text { Latosol } \\
\text { 3. }\end{array}$ & $\begin{array}{l}\text { Brown Forest Soil, Non Calcik Brown, } \\
\text { Mediteranian }\end{array}$ & 30 \\
4. & $\begin{array}{l}\text { Andosol, Laterik, Grumosol, Podsol, } \\
\text { 5ekaan Sedang }\end{array}$ & 45 \\
5. & Podsolik & Pegosol, Litosol, Renzina & 60 \\
Sumber: & Surat Keputusan Menteri Pertanian Nomor $837 /$ Kpts/Um/11/1980
\end{tabular}

Pemberian skor menurut tingkat kepekaan tanah terhadap erosi yang dapat menyebabkan longsor dibagi dalam 5 kelas dapat dilihat pada Tabel 2 .
Intensitas curah hujan yang tinggi pada suatu daerah akan memberikan bahaya gerakan tanah atau longsor yang sangat tinggi. Pemberian skor menurut intensitas curah hujan dapat dilihat pada Tabel 3.

Tabel 3. Kelas intensitas curah hujan dan nilai skor

\begin{tabular}{cccc}
\hline Kelas & Kriteria $(\mathrm{mm} /$ hari) & Keterangan & Skor \\
\hline 1. & $0-13,6$ & Sangat Rendah (Tidak Peka) & 10 \\
2. & $13,6-20,7$ & Rendah (Agak Peka) & 20 \\
3. & $20,7-27,7$ & Sedang (Kepekaan Sedang) & 30 \\
4. & $27,7-34,8$ & Tinggi (Peka) & 40 \\
5. & $>34,8$ & Sangat Tinggi (Sangat Peka) & 50
\end{tabular}

Sumber: Surat Keputusan Menteri Pertanian Nomor 837/Kpts/Um/11/1980

\section{Klasifikasi Tingkat Kerawanan Longsor}

Tingkat kerawanan longsor dibagi dalam tiga kelas berdasarkan hasil penjumlahan skor dari tiga variabel utama dan dilakukan penetapan kecocokan penggunaan lahan sesuai dengan Surat Keputusan Menteri Pertanian Nomor 
$837 / \mathrm{Kpts} / \mathrm{Um} / 11 / 1980 \quad$ tanggal 24 November 1980 tentang Kriteria dan Tata Cara Penetapan Hutan Lindung dan Surat Keputusan Menteri Pertanianan Nomor 683/Kpts/Um/8/1981 tanggal 8 Agustus 1981 tentang Kriteria dan Tata Cara Penetapan Hutan Produksi. Penetapan kecocokan penggunaan lahan dilakukan dengan bertujuan agar suatu lahan dapat digunakan secara semaksimal mungkin sehingga tidak terjadi penurunan kualitas lahan (Asdak 1995) dalam Hematang (2011).

Tabel 4. Kelas kerawanan dan kecocokan penggunaan lahan

\begin{tabular}{clcl}
\hline Kelas & Keterangan & Total Skor & \multicolumn{1}{c}{ Kecocokan Lahan } \\
\hline 1. & Rawan & $\geq 175$ & Kawasan Lindung \\
2. & Kerawanan Sedang & $125-174$ & Kawasan Penyangga \\
3. & Tidak Rawan & $\leq 124$ & Kawasan Budidaya Tanaman \\
& & & Tahunan, Tanaman Kehutanan, \\
& & & Musiman, dan Pemukiman \\
\hline
\end{tabular}

Sumber: Modifikasi dari SK Mentan Nomor 837/Kpts/Um/11/1980 dan SK Mentan Nomor 683/Kpts/Um/8/1981 tanggal 8 Agustus 1981

\section{Analisis Data}

Analisis spasial adalah sekumpulan teknik yang dapat digunakan dalam pengolahan data SIG. Hasil analisis data spasial sangat bergantung pada lokasi objek yang bersangkutan (yang sedang dianalisis). Analisis spasial juga dapat diartikan sebagai teknik-teknik yang digunakan untuk meneliti dan mengeksplorasi data dari perspektif keruangan. Semua teknik atau pendekatan perhitungan matematis yang terkait dengan data keruangan (spasial) dilakukan dengan fungsi analisis spasial tersebut (Handayani dkk. 2005).

Data-data penelitian akan dianalisis secara spasial untuk diambil sebuah kesimpulan akhir tentang tingkat kerentanan longsor di Kawasan CAPA. Data hasil akan disajikan dalam bentuk peta dan tabulasi serta gambar.

HASIL DAN PEMBAHASAN Wilayah CAPA

CAPA memiliki luas 68.325 Ha berdasarkan Surat Keputusan Menteri
Kehutanan No. 783/Kpts-II/1992. Secara geografis kawasan Cagar Alam Pegunungan Arfak terletak antara $133^{\circ} 53^{\prime}-134^{\circ} 13^{\prime}$ BT dan $01^{\circ}-01^{\circ} 28^{\prime} \mathrm{LS}$, membentang sepanjang $\pm 243.376 \mathrm{~km}$ dan secara administratif pada tiga wilayah Kabupaten yakni Kabupaten Manokwari, Kabupaten Manokwari Selatan dan Kabupaten Pegunungan Arfak.

Sumber data Cagar Alam Pegunungan Arfak berasal dari 3 sumber yaitu: 1) data shape file (shp.) dari Balai Pemantapan Kawasan Hutan Wilayah XVII Manokwari dengan luas 83.332,90 Ha; 2) data shape file (shp.) di ekstrak dari SK 783/Menhut-II/2014 tentang Fungsi Kawasan Konservasi Hutan \& Perairan dengan luas $82.050 \mathrm{Ha}$; dan 3) data dari Surat Keputusan Menteri Kehutanan No. 783/Kpts-II/1992 dengan luas $62.325 \mathrm{Ha}$. Jadi dalam penelitian ini data batas luas Kawasan Cagar Alam Pegunungan Arfak yang digunakan mengacu pada data 83.332,90 Ha. 


\section{Kelerengan CAPA}

Kelas lereng dibagi menjadi lima kelas dengan pemberian skor sesuai dengan Surat Keputusan Menteri Pertanian
Nomor $837 / \mathrm{Kpts} / \mathrm{Um} / 11 / 1980$ tanggal 24 November 1980 tentang Kriteria dan Tata Cara Penetapan Hutan Lindung dan dapat dilihat pada Tabel 3.

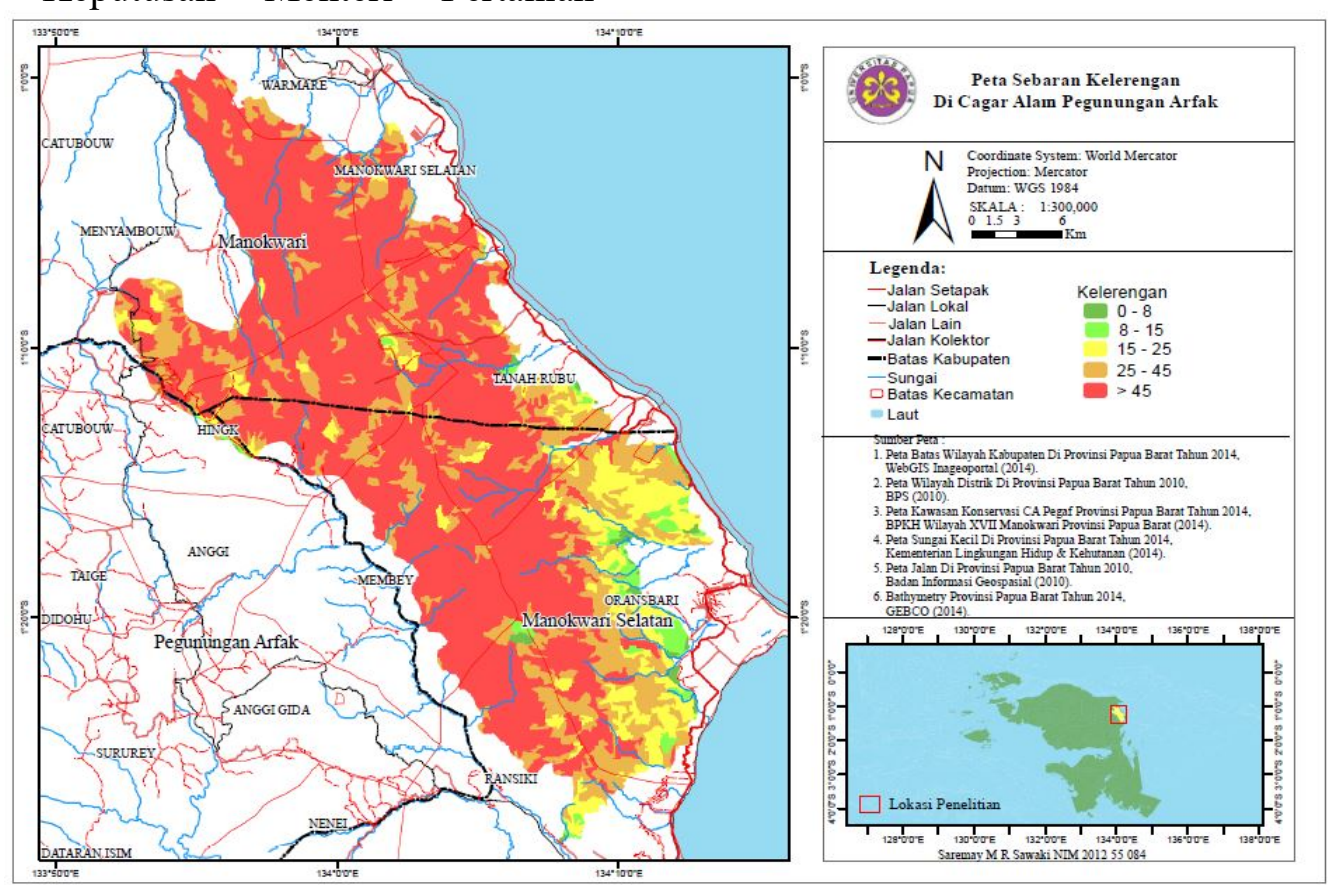

Gambar 3. Peta sebaran kelerengan di kawasan Cagar Aalam Pegunungan Arfak

Kelas lereng CAPA dapat dilihat pada Gambar 3 warna merah menunjukkan kawasan dengan tingkat kelerengan sangat curam atau $>45 \%$, warna oranye menunjukkan kawasan dengan tingkat kelerengan curam atau tingkat kelerengan antara 25-45\%, warna kuning menunjukkan kawasan dengan tingkat kelerengan agak curam atau tingkat kelerengan antara $15-25 \%$, warna hijau muda menunjukan kawasan dengan tingkat kelerengan landai atau tingkat kelerengan antara $8-15 \%$ serta warna hijau tua menunjukkan kawasan dengan tingkat kelerengan datar atau tingkat kelerengan antara 0-8\%. Luas lereng per kelas kelerengan dapat di lihat pada Tabel 5 .

Tabel 5. Luas lereng di kawasan CAPA

\begin{tabular}{ccc}
\hline Lereng $(\%)$ & Luas Per Kelas Ha & Persentase (\%) \\
\hline $0-8$ & 659.41 & 0.79 \\
$8-15$ & 1930.70 & 2.31 \\
$15-25$ & 7860.19 & 9.43 \\
$25-40$ & 19077.36 & 22.89 \\
$>40$ & 53805.21 & 64.56 \\
Total & 83332.90 & 100 \\
\hline
\end{tabular}




\section{Jenis Tanah di Cagar Alam Pegunungan Arfak}

Jenis tanah dibagi menjadi lima kelas dengan pemberian skor sesuai dengan Surat Keputusan Menteri Pertanian Nomor $837 / \mathrm{Kpts} / \mathrm{Um} / 11 / 1980$ tanggal 24 November 1980 tentang Kriteria dan Tata Cara Penetapan Hutan Lindung dan dapat dilihat pada Tabel 6. Jenis tanah pada CAPA dapat dilihat pada Gambar 4 terdapat empat jenis tanah pada CAPA pada yaitu alluvial dengan simbol warna cokelat tua, latosol dengan simbol warna meraah, mediteranean dengan simbol warna putih kekuningan dan podsolik dengan simbol warna merah kekuningan. Tanah aluvial merupakan tanah endapan, dibentuk dari lumpur dan pasir halus yang mengalami erosi tanah (Prasetyo dan Setyorini 2008).

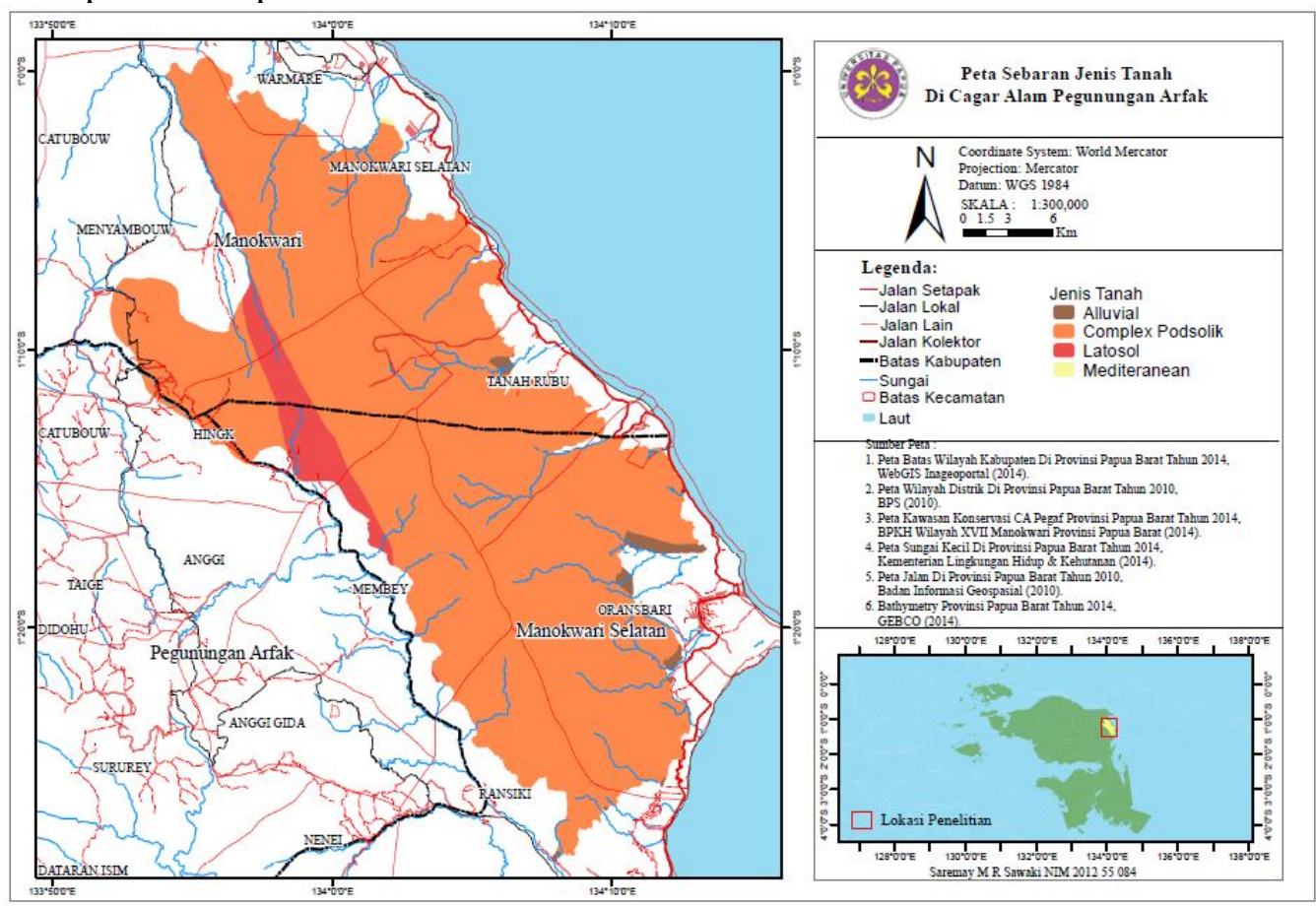

Gambar 4. Peta sebaran jenis tanah di kawasan Cagar Aalam Pegunungan Arfak.

Tanah latosol atau tanah insepticol merupakan tanah yang mempunyai lapisan solum. Lapisan solum yang dimiliki oleh tanah latosol ini cenderung tebal dan bahkan sangat tebal. Lapisan solum tanah ini antara $130 \mathrm{~cm}$ hingga 5 meter dan bahkan lebih. Tanah kapur disebut juga dengan tanah mediteran, yakni salah satu jenis tanah yang tidak memiliki unsur hara, atau memiliki unsur hara namun hanya dalam jumlah yang sedikit sekali. Tanah kapur ini disebit juga dengan tanah mediteran karena memiliki atri terbentuk dari bebatuan kapur yang yang telah lapuk dan hancur. Tanah podsolik merah kuning atau sering disingkat PMK adalah tanah yang terbentuk karena curah hujan yang tinggi dan suhu yang sangat rendah dan juga merupakan jenis tanah mineral tua yang memiliki warna kekuningan atau 
kemerahan (Prasetyo 2009). Luas sebaran jenis tanah dapat dilihat pada Tabel 6.

Tabel 6. Luas sebaran jenis tanah di kawasan CAPA

\begin{tabular}{ccc}
\hline Jenis Tanah & Luas $(\mathrm{Ha})$ & Persentase (\%) \\
\hline Alluvial & 865.62 & 1.03 \\
Complex Podsolik & 78536.79 & 94.33 \\
Latosol & 3814.35 & 4.58 \\
Mediteranean & 34.24 & 0.04 \\
Total & 83251.02 & 100 \\
\hline
\end{tabular}

\section{Curah Hujan di kawasan CAPA}

Curah hujan dibagi menjadi lima kelas dengan pemberian skor sesuai dengan Surat Keputusan Menteri Pertanian Nomor $837 / \mathrm{Kpts} / \mathrm{Um} / 11 / 1980$ tanggal 24 November 1980 tentang Kriteria dan Tata Cara Penetapan Hutan Lindung. Curah hujan pada Cagar Alam Pegunungan
Arfak tahun 2015 dapat dilihat pada Gambar 6. Berdasarkan data curah hujan dari BMKG dari tahun 2011 sampai tahun 2016 jumlah rata-rata curah hujan per hari di Kawasan Cagar Alam Pegunungan Arfak dalam 6 tahun terakhir adalah $12,47 \mathrm{~mm} / \mathrm{thn}$ atau dapat dikatakan curah hujannya sangat rendah.

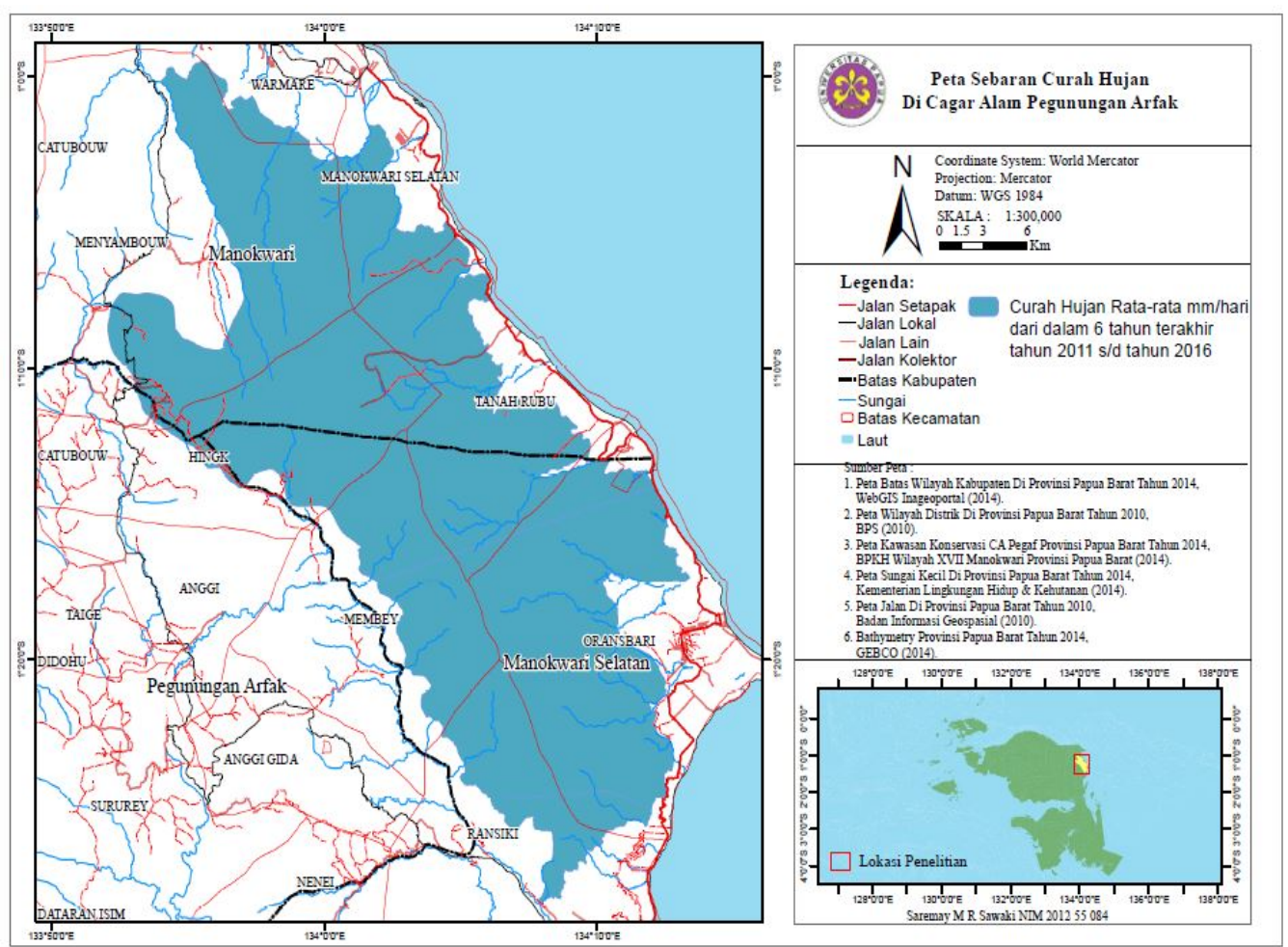

Gambar 5. Peta sebaran kelerengan di kawasan Cagar Aalam Pegunungan Arfak. 


\section{Daerah Sebaran Rawan Longsor dan Kecocokan Lahan}

Tingkat kerawanan longsor dibagi dalam tiga kelas berdasarkan hasil penjumlahan skor dari tiga variabel utama dan dilakukan penetapan kecocokan penggunaan lahan sesuai dengan Surat Keputusan Menteri Pertanian Nomor $837 / \mathrm{Kpts} / \mathrm{Um} / 11 / 1980$ tanggal 24 November 1980 tentang Kriteria dan Tata Cara Penetapan Hutan Lindung dan Surat Keputusan Menteri Pertanianan Nomor 683/Kpts/Um/8/1981 tanggal 8 Agustus
1981 tentang Kriteria dan Tata Cara Penetapan Hutan Produksi. Berdasarkan hasil overlay dari data spasial kelerengan, jenis tanah dan curah hujan maka daerah sebaran desa pada daerah rawan longsor dan kecocokan lahan dapat dilihat pada Gambar 6. Berdasarkan Gambar 6, maka dapat diketahui luas daerah rawan longsor, persentase luas daerah dan kecocokan lahan di Cagar Alam Pegunungan Arfak yang dapat dilihat pada Tabel 7.

Tabel 7. Luas daerah rawan longsor dan kecocokan lahan

\begin{tabular}{lrrr}
\multicolumn{1}{c}{ Kelas Kerawanan } & \multicolumn{1}{c}{ Luas Ha } & Persentase (\%) & \multicolumn{1}{c}{ Kecocokan Lahan } \\
\hline Tidak Rawan & 3681.65 & 4.42 & Kawasan Budidaya \\
Kerawanan Sedang & 25815.58 & 31.00 & Kawasan Penyangga \\
Rawan & 53753.78 & 64.56 & Kawasan Lindung \\
\multicolumn{1}{c}{ Total } & 83251.02 & 100 & \\
\hline
\end{tabular}

Sumber: Hasil Overlay data spasial

CAPA didominasi oleh daerah kelas 1 atau kerawanan longsornya rawan dengan luas sekitar $64,56 \%$ dan direkomendasikan sebagai kawasan lindung. Daerah dengan tingkat kerawanan sedang atau kelas 2 dengan luas $31 \%$ direkomendasikan sebagai kawasan penyangga dan daerah dengan luas $4,42 \%$ atau daerah kelas tidak rawan direkomendasikan sebagai kawasan budidaya. Terdapat 4 kampung yang berada pada daerah dengan tingkat kerawanan tidak rawan, yaitu: Kampung Bomboy, Kampung Demunti, Kampung Mbegau, Kampung Kisap. Terdapat 14 kampung yang berada pada daerah dengan tingkat kerawanan sedang, yaitu: Kampung Minyemeimut, Kampung
Leiheak, Kampung Ngimoubre, Kampung Nungkimor, Kampung Umnum, Kampung Sopnyai, Kampung Tingkwoikiu, Kampung Imboiti, Kampung Micadwor, Kampung Urwong, Kampung Binguoyut, Kampung Imbongun, Kampung Demaisi dan Kampung Apui. Sedangkan pada daerah dengan tingkat rawan terdapat 13 kampung, yaitu: Kampung Kwok Dua, Kampung Misapngoisi, Kampung Imbasika Dua, Kampung Imbrekti, Kampung Memangker, Kampung Mbatma, Kampung Kipuauw, Kampung Enam, Kampung Anggra, Kampung Smerbei, Kampung Ayau, Kampung Imbenti dan Kampung Ungkopti. 


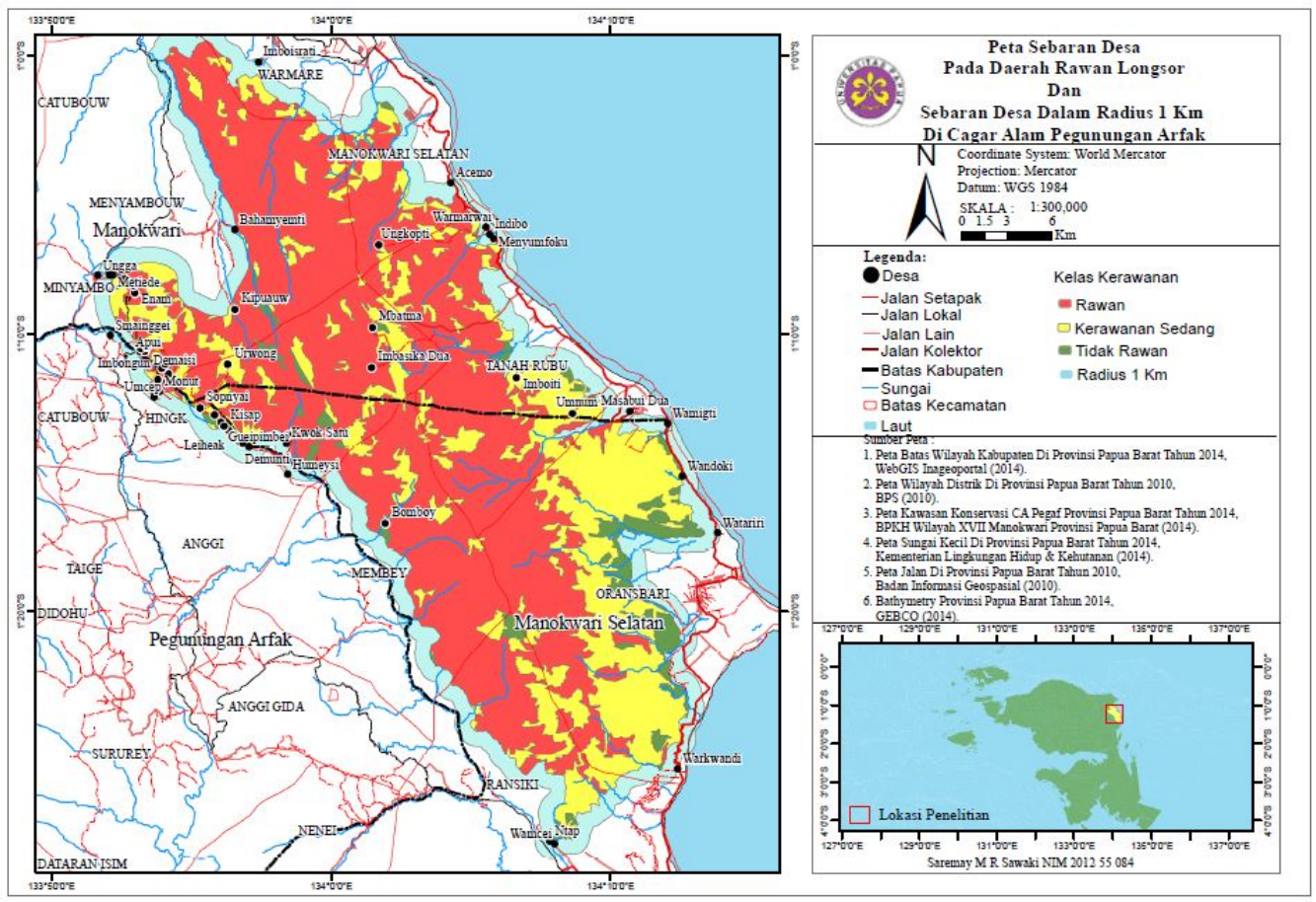

Gambar 6. Peta sebaran desa pada daerah rawan longsor dan sebaran desa dalam radius 1 km di kawasan Cagar Aalam Pegunungan Arfak.

Terdapat 22 kampung yang terdapat dalam radius 1 kilometer $(\mathrm{km})$ dari daerah pada ketiga kelas kerawanan, yaitu: Kampung Wamcei, Kampung Ntap, Kampung Warkwandi, Kampung Watariri, Kampung Wandoki, Kampung Humeysi , Kampung Gueipimbei, Kampung Kwok Satu, Kampung Wamigti, Kampung Masabui Dua, Kampung Umcep, Kampung Monut, Kampung Smainggei, Kampung Ungga, Kampung Metiede, Kampung Minyambo, Kampung Menyumfoku, Kampung Indibo, Kampung Bahamyemti, Kampung
Warmarwai, Kampung Acemo, Kampung Imboisrati. Kawasan lindung atau rawan adalah daerah yang sudah pernah terjadi longsor dan sangat rentan untuk terjadi longsor sehingga harus menjadi kawasan lindung. Kawasan penyangga atau kerawanan sedang adalah daerah yang rentan untuk terjadi longsor dan bisa saja terjadi jika tutupan lahan atau pohon yang berada di daerah tersebut di tebang. Sementara kawasan budidaya atau daerah tidak rawan merupakan daerah yang tidak rentan terjadi longsor. 

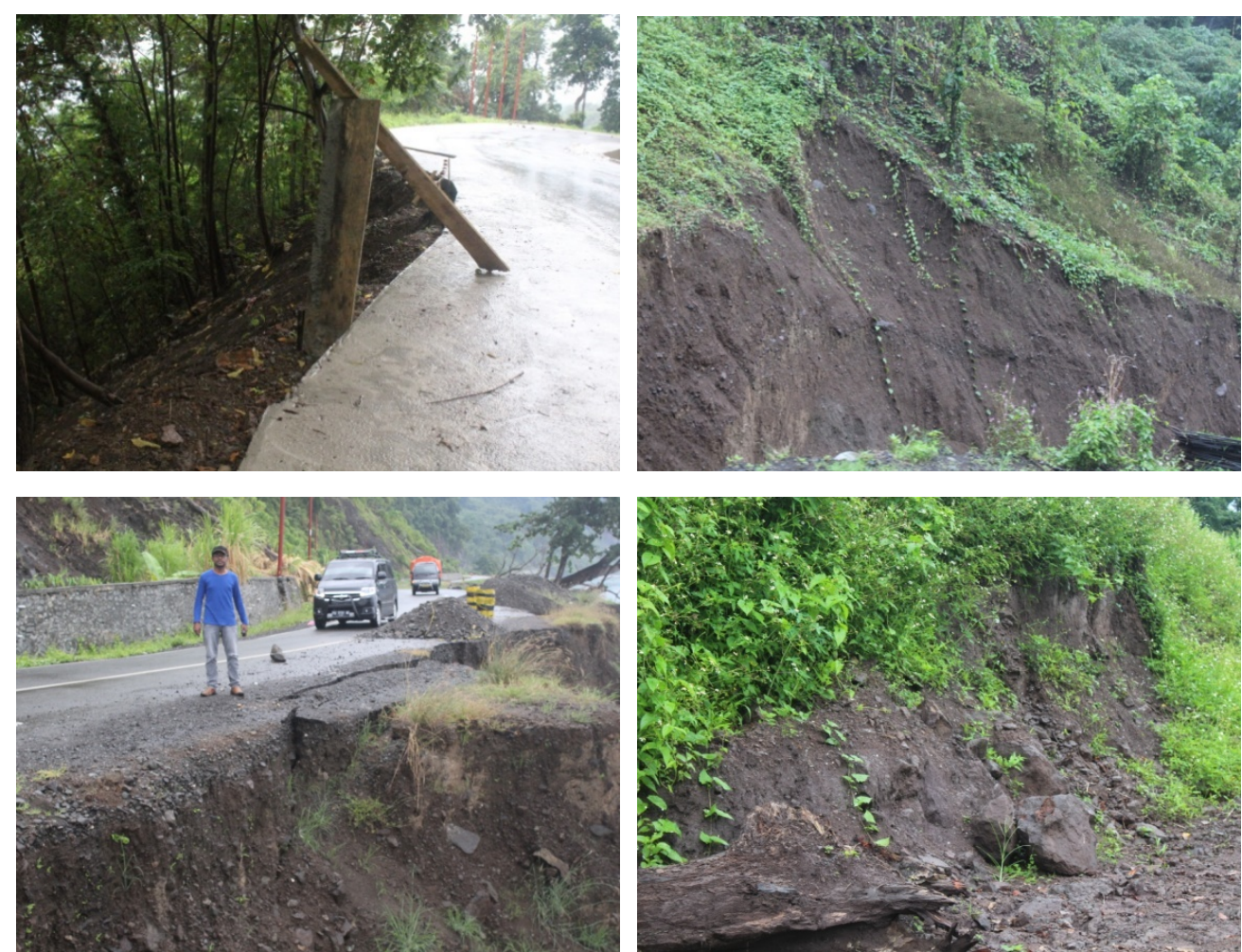

Gambar 7. Gambaran umum beberapa areal yang masuk dalam kategosi rawan longsor di sekitar CAPA. kiri atas merupakan area rawan longsor pada jalan disekitar Kampung Acemo; kanan atas merupakan daerah rawan longsor di Distik Tanah Rubu; kiri bawah merupakan gambaran longsor pada sisi jalan di Distrik Tana Rubuh; kanan bawah merupakan gambaran longsor yang terjadi di Bembab.

\section{DAFTAR PUSTAKA}

Badan Nasional Penanggulangan

Bencana. 2009. Kajian tentang penanggulangan bencana alam di Indonesia. Laporan Akhir Jilid 2. Rencana Nasional Penanggulangan Bencana. Japan International Cooperation Agency. Oriental Consultants CO., LTD.

Budiyanto E. 2016. Sistem informasi geografis dengan quantum GIS. Yogyakarta: Penerbit Andi.

Cahaya Papua. 2006. Pegunungan Arfak mengalami longsor. Koran Cahaya Papua terbitan Agustus 2016.
Handayani D, UNR Soelistijadi dan Sunardi. 2005. Pemanfaatan analisis spasial untuk pengolahan data spasial system informasi geografis. Jurnal Teknologi Informasi DINAMIK, Vol 10 (2): 108-116.

Hematang. FL. 2011. Analis pendugaan kawasan rentan banjir berbasis sistem informasi geografis (SIG) DI Kabupaten Teluk Wondama Propinsi Papua Barat [skripsi]. Manokwari: Fakultas Kehutanan, Univerrsitas Negeri Papua. (Tidak diterbitkan).

Prasetyo BH dan Setyorini D. 2008. Karakteristik tanah sawah dari 
endapan alluvial dan pengelolaannya. Jurnal Sumberdaya Lahan, Vol 2(1): 114.

Prasetyo BH. 2009. Tanah merah dari berbagai bahan induk di Indonesia: Prospek dan strategi pengelolaannya. Jurnal Sumberdaya Lahan, vol 3 (1): 47-60.

Suaib dan Qashlim A. 2016. Sistem inventarisasi daerah rawan bencana berbasis GIS (Studi kasus: Kecamatan Tapalang, Sulawesi Barat). Jurnal Invotek Polbeng - Seri Infomatika, Vol 1 (2): 140-147.

Yu M, Yang C and Li Y. 2018. Big data in natural disaster management: A review. Geosciences, 8, 165; doi: $10.3390 /$ geosciences 8050165 .

Tabel 8. Jumlah skor pada kelas tidak rawan

\begin{tabular}{|c|c|c|c|c|c|c|}
\hline Tanah & Skor & Lereng (\%) & Skor & Hujan & Skor & Total \\
\hline Alluvial & 15 & $0-8$ & 20 & $1500-2000 \mathrm{~mm} /$ tahun & 30 & 65 \\
\hline Alluvial & 15 & $0-8$ & 20 & $2000-2500 \mathrm{~mm} /$ tahun & 30 & 65 \\
\hline Alluvial & 15 & $0-8$ & 20 & $2500-3000 \mathrm{~mm} /$ tahun & 40 & 75 \\
\hline
\end{tabular}

Sumber: Hasil Overlay data spasial

Tabel 9. Jumlah skor pada kelas kerawanan sedang

\begin{tabular}{|c|c|c|c|c|c|c|}
\hline Tanah & Skor & Lereng (\%) & Skor & Hujan & Skor & Total \\
\hline Alluvial & 15 & $8-15$ & 40 & $1500-2000 \mathrm{~mm} /$ tahun & 30 & 85 \\
\hline Alluvial & 15 & $8-15$ & 40 & $2000-2500 \mathrm{~mm} /$ tahun & 30 & 85 \\
\hline Alluvial & 15 & $8-15$ & 40 & $2500-3000 \mathrm{~mm} /$ tahun & 40 & 95 \\
\hline Alluvial & 15 & $15-25$ & 60 & $1500-2000 \mathrm{~mm} /$ tahun & 30 & 105 \\
\hline Alluvial & 15 & $15-25$ & 60 & $2000-2500 \mathrm{~mm} /$ tahun & 30 & 105 \\
\hline Alluvial & 15 & $15-25$ & 60 & $2500-3000 \mathrm{~mm} /$ tahun & 40 & 115 \\
\hline Podsolik & 60 & $0-8$ & 20 & $1500-2000 \mathrm{~mm} /$ tahun & 30 & 110 \\
\hline Podsolik & 60 & $0-8$ & 20 & $2000-2500 \mathrm{~mm} /$ tahun & 30 & 110 \\
\hline
\end{tabular}

Sumber: Hasil Overlay data spasial

Tabel 10. Jumlah skor pada kelas kerawanan sedang

\begin{tabular}{|c|c|c|c|c|c|c|}
\hline Tanah & Skor & Lereng (\%) & Skor & Hujan & Skor & Total \\
\hline Podsolik & 60 & $25-45$ & 80 & & 0 & 140 \\
\hline Alluvial & 15 & $25-45$ & 80 & $2000-2500 \mathrm{~mm} /$ tahun & 30 & 125 \\
\hline Alluvial & 15 & $25-45$ & 80 & $2000-2500 \mathrm{~mm} /$ tahun & 30 & 125 \\
\hline Alluvial & 15 & $25-45$ & 80 & $2500-3000 \mathrm{~mm} /$ tahun & 40 & 135 \\
\hline Alluvial & 15 & $>45$ & 100 & $1500-2000 \mathrm{~mm} /$ tahun & 30 & 145 \\
\hline Alluvial & 15 & $>45$ & 100 & $2500-3000 \mathrm{~mm} /$ tahun & 40 & 155 \\
\hline Podsolik & 60 & $0-8$ & 20 & $2500-3000 \mathrm{~mm} /$ tahun & 40 & 120 \\
\hline Podsolik & 60 & $0-8$ & 20 & $2500-3000 \mathrm{~mm} /$ tahun & 40 & 120 \\
\hline Podsolik & 60 & $0-8$ & 20 & $2500-3000 \mathrm{~mm} /$ tahun & 40 & 120 \\
\hline
\end{tabular}




\begin{tabular}{|c|c|c|c|c|c|c|}
\hline Podsolik & 60 & $8-15$ & 40 & $2500-3000 \mathrm{~mm} /$ tahun & 40 & 140 \\
\hline Podsolik & 60 & $8-15$ & 40 & $1500-2000 \mathrm{~mm} /$ tahun & 30 & 130 \\
\hline Podsolik & 60 & $8-15$ & 40 & $2000-2500 \mathrm{~mm} /$ tahun & 30 & 130 \\
\hline Podsolik & 60 & $8-15$ & 40 & $2500-3000 \mathrm{~mm} /$ tahun & 40 & 140 \\
\hline Podsolik & 60 & $8-15$ & 40 & $2500-3000 \mathrm{~mm} /$ tahun & 40 & 140 \\
\hline Podsolik & 60 & $15-25$ & 60 & $1500-2000 \mathrm{~mm} /$ tahun & 30 & 150 \\
\hline Podsolik & 60 & $15-25$ & 60 & $2000-2500 \mathrm{~mm} /$ tahun & 30 & 150 \\
\hline Latosol & 30 & $15-25$ & 60 & $2500-3000 \mathrm{~mm} /$ tahun & 40 & 130 \\
\hline Latosol & 30 & $15-25$ & 60 & $2500-3000 \mathrm{~mm} /$ tahun & 40 & 130 \\
\hline Latosol & 30 & $25-45$ & 80 & $2500-3000 \mathrm{~mm} /$ tahun & 40 & 150 \\
\hline Latosol & 30 & $25-45$ & 80 & $2000-2500 \mathrm{~mm} /$ tahun & 30 & 140 \\
\hline Latosol & 30 & $25-45$ & 80 & $2500-3000 \mathrm{~mm} /$ tahun & 40 & 150 \\
\hline Mediteranean & 45 & $15-25$ & 60 & $2500-3000 \mathrm{~mm} /$ tahun & 40 & 145 \\
\hline
\end{tabular}

Sumber: Hasil Overlay data spasial

Tabel 11. Jumlah skor dari kelas rawan

\begin{tabular}{|c|c|c|c|c|c|c|}
\hline Tanah & Skor & Lereng (\%) & Skor & Hujan & Skor & Total \\
\hline Podsolik & 60 & $>45$ & 100 & & 0 & 160 \\
\hline Podsolik & 60 & $15-25$ & 60 & $2500-3000 \mathrm{~mm} /$ tahun & 40 & 160 \\
\hline Podsolik & 60 & $15-25$ & 60 & $2500-3000 \mathrm{~mm} /$ tahun & 40 & 160 \\
\hline Podsolik & 60 & $15-25$ & 60 & $2500-3000 \mathrm{~mm} /$ tahun & 40 & 160 \\
\hline Podsolik & 60 & $25-45$ & 80 & $2500-3000 \mathrm{~mm} /$ tahun & 40 & 180 \\
\hline Podsolik & 60 & $25-45$ & 80 & $1500-2000 \mathrm{~mm} /$ tahun & 30 & 170 \\
\hline Podsolik & 60 & $25-45$ & 80 & $2000-2500 \mathrm{~mm} /$ tahun & 30 & 170 \\
\hline Podsolik & 60 & $25-45$ & 80 & $2500-3000 \mathrm{~mm} /$ tahun & 40 & 180 \\
\hline Podsolik & 60 & $25-45$ & 80 & $2500-3000 \mathrm{~mm} /$ tahun & 40 & 180 \\
\hline Podsolik & 60 & $>45$ & 100 & $1500-2000 \mathrm{~mm} /$ tahun & 30 & 190 \\
\hline Podsolik & 60 & $>45$ & 100 & $2000-2500 \mathrm{~mm} /$ tahun & 30 & 190 \\
\hline Latosol & 30 & $>45$ & 100 & $2500-3000 \mathrm{~mm} /$ tahun & 40 & 170 \\
\hline Latosol & 30 & $>45$ & 100 & $2000-2500 \mathrm{~mm} /$ tahun & 30 & 160 \\
\hline Latosol & 30 & $>45$ & 100 & $2500-3000 \mathrm{~mm} /$ tahun & 40 & 170 \\
\hline Mediteranean & 45 & $25-45$ & 80 & $2500-3000 \mathrm{~mm} /$ tahun & 40 & 165 \\
\hline
\end{tabular}

Sumber: Hasil Overlay data spasial

Tabel 12. Jumlah skor pada kelas sangat rawan

\begin{tabular}{|c|c|c|c|c|c|c|}
\hline Tanah & Skor & Lereng (\%) & Skor & Hujan & Skor & Total \\
\hline Podsolik & 60 & $>45$ & 100 & $2500-3000 \mathrm{~mm} /$ tahun & 40 & 200 \\
\hline Podsolik & 60 & $>45$ & 100 & $2500-3000 \mathrm{~mm} /$ tahun & 40 & 200 \\
\hline Podsolik & 60 & $>45$ & 100 & $2500-3000 \mathrm{~mm} /$ tahun & 40 & 200 \\
\hline
\end{tabular}

Sumber: Hasil Overlay data spasial 